\title{
Peningkatan Kapasitas Kelompok Tani Jaya Makmur Kurik Merauke melalui Pelatihan Pembuatan Asap Cair Sekam Padi sebagai Biopestisida Organik
}

\section{(Capacity Empowerment Farmer Group of Jaya Makmur Kurik Merauke through Training Rice Husk Liquid Smoke Production Become Organic Bio-Pesticides)}

\author{
Maria Maghdalena Diana Widiastuti ${ }^{*}$, Yosefina Mangera ${ }^{2}$, Jamaludin ${ }^{2}$, Andriyono ${ }^{3}$, \\ Nurhening Yuni Ekowati ${ }^{4}$ \\ 1 Jurusan Agribisnis, Fakultas Pertanian, Universitas Musamus, Jl. Kamizaun Mopah Lama, Rimba Jaya, \\ Kabupaten Merauke, Papua 99611. \\ 2 Jurusan Ketehnikan Pertanian, Fakultas Pertanian, Universitas Musamus, Jl. Kamizaun Mopah Lama Rimba Jaya, \\ Kabupaten Merauke, Papua 99611. \\ 3 Jurusan Tehnik Mesin, Fakultas Pertanian, Universitas Musamus, Jl. Kamizaun Mopah Lama Rimba Jaya, \\ Kabupaten Merauke, Papua 99611. \\ ${ }^{4}$ Jurusan Agroteknologi, Fakultas Pertanian, Universitas Musamus, Jl. Kamizaun Mopah Lama Rimba Jaya, \\ Kabupaten Merauke, Papua 99611. \\ *Penulis Korespondensi: mariawidiastuti@unmus.ac.id \\ Diterima Agustus 2019/Disetujui Januari 2020
}

\begin{abstract}
ABSTRAK
Pemakaian pestisida kimia kerap dilakukan petani dan seringkali mengabaikan dosis yang disarankan. Pemakaiannya menghabiskan $20 \%$ anggaran usaha tani, dan demi peningkatan produksi, keamanan pangan terabaikan. Tujuan peningkatan kapasitas ini adalah memberikan pengetahuan pembuatan asap cair dari limbah pertanian sekam padi sebagai biopestisida organik pengganti pestisida kimia bagi kelompok tani di Kampung Jaya Makmur, Kabupaten Merauke. Metode pelaksanaan kegiatan adalah dengan pelatihan dan pendampingan proses pembuatan asap cair dan desiminasi kepada petani untuk membantu proses pembuatan dan pemasaran produk asap cair. Hasil pengabdian ini adalah drum kiln (alat pembuat biochar) termodifikasi dengan menggunakan metode pirolisis. Alat tersebut telah melalui proses uji coba dan telah dipakai dalam training proses pembuatan asap cair kepada kelompok tani Jaya Makmur yang diikuti oleh 26 orang petani, 2 orang petani pioneer, 3 orang mahasiswa, dan 9 orang dosen Fakultas Pertanian dan Fakultas Teknik Mesin. Pengabdian ini dilanjutkan dengan program pendampingan kepada kelompok sentra produksi biochar dan asap cair melalui pelatihan menghitung biaya operasional pembuatan asap cair, pengemasan produk, dan analisis peluang penjualan asap cair sebagai biopestisida di kalangan petani. Kesimpulan kegiatan ini adalah telah terjadi peningkatan pengetahuan di kalangan petani dari $20,3 \%$ menjadi $57 \%$. Melalui proses pendampingan, kelompok tani mampu membuat salah satu sarana pertanian yaitu biopestisida.
\end{abstract}

Kata kunci: asap cair, biochar, biopestisida, kiln drum

\begin{abstract}
Farmers ussually use chemical pesticides and mostly ignore the recommended dosage. Chemical pesticides spend $20 \%$ of farming expenses, and for the sake of production increase, food safety become is neglected. The purpose of this community capacity building was to increase farmers knowledge in making liquid smoke from rice husk as biopesticides for farmer groups in Kampung Jaya Makmur, Merauke Regency. The method was by conducting training and mentoring of liquid smoke production, and assisting the process of marketing liquid smoke products. The results were a modified kiln drum (biochar maker) into a liquid smoke maker using the pyrolysis method. This kiln has been used for trial process and used for training to farmers group of Jaya Makmur. The liquid smoke peocess training was attended by 26 farmers, 2 pioneer farmers, 3 students, and 9 lecturers from the Faculty of Agriculture and the Faculty of Engineering Musamus University. The capacity building was followed by assisting program for biochar and liquid smoke production. This activity included calculating operational costs of liquid smoke production, product packaging, and opportunity analysis of selling liquid smoke as biopesticides organic among the farmers. Conclusion of this capacity building was the increase farmers knowledge from $20.3 \%$ to $57 \%$. Through the assistance, the farmer group can make biopestiside as one of agricultural production inputs.
\end{abstract}

Keywords: biochar, biopesticides, kiln drum, smoke liquid 


\section{PENDAHULUAN}

Program Iptek bagi Masyarakat di Kampung Jaya Makmur pada tahun 2016 telah menghasilkan kelompok sentra produksi biochar (Widiastuti \& Lantang 2017). Kelompok ini telah memiliki setidaknya 3 jenis alat pembakaran sekam padi, yaitu drum pembakaran (kiln drum), tiang pembakaran, dan kawat ram. Hampir semua anggota kelompok lebih senang menggunakan kawat ram atau tiang bakaran dibandingkan dengan kiln drum dari ketiga alat pembakaran tersebut. Menggunakan tiang bakaran relatif lebih mudah cara pembuatannya dan hasil yang diperoleh dapat lebih banyak dibandingkan dengan menggunakan kiln drum. Namun, di sisi lain pemakaian tiang bakaran dan kawat ram akan menghasilkan banyak asap yang mengganggu lingkungan sekitar pada saat proses pembakaran sekam. Rupanya, petani lebih mengutamakan efesiensi dibandingkan kesehatan. Oleh karena itu kiln drum tidak lagi digunakan oleh anggota kelompok sentra produksi biochar.

Program Pengabdian kepada Masyarakat (PKM) pada tahun 2019 ini ditujukan untuk merangsang masyarakat agar mau menggunakan kiln drum supaya lebih sehat dalam memproduksi biochar dan juga dapat menghasilkan produk tambahan berupa asap cair yang diperuntukkan untuk biopestisida organik. Diharapkan dengan didesiminasikannya teknologi pembuatan asap cair dari modifikasi kiln drum, masyarakat termotivasi untuk membuat biochar dengan lebih sehat, mampu membuat asap cair dan juga mengupayakan pertanian organik dengan menggunakan biopestisida sebagai pengganti pestisida kimia yang sering digunakan oleh masyarakat.

Dilihat dari aktivitas yang selama ini telah dilakukan, kelompok tani Jaya Makmur dan kelompok sentra produksi biochar merupakan kelompok mitra yang dapat diarahkan ke ekonomi produktif kelompok. Hal ini karena sejak tahun 2014 kelompok tani ini telah diperkenalkan tentang biochar, teknologi proses pembuatannya dan aplikasi di lahan pertanian mereka. Bahkan beberapa petani telah mengupayakan penjualan biochar dan menjadi pemasukan tambahan dalam usaha pertanian mereka.

Komoditas asap cair yang menjadi inovasi tambahan ini berasal dari modifikasi kiln drum pembuat biochar. Gambar 1 memperlihatkan kiln drum pembuat biochar yang akan dimodifikasi. Kiln drum ini tidak saja akan menghasilkan biochar namun juga akan menangkap asap yang dihasilkan dari proses pembakaran menjadi asap cair. Komoditas asap cair merupakan produk baru di Merauke. Komoditas ini sangat potensial untuk dikembangkan mengingat fungsinya yang sangat penting bagi industri pengawetan makanan dan pengembangan pertanian organik. Aplikasi asap cair sebagai biopestisida belum pernah dilakukan di Merauke. Selama ini masyarakat hanya menggunakan pestisida kimia untuk mengatasi hama dan penyakit. Sebanyak $20 \%$ biaya analisis usaha tani padi sawah digunakan untuk biaya pembelian pestisida (Widiastuti 2018). Oleh karena itu, pemakaian biopestisida yang berasal dari limbah biochar sekam padi dapat dijadikan alternatif untuk mengurangi pemakaian pestisida kimia.

Menurut BPS Kabupaten Merauke (2017), lahan pertanian yang ada di Kabupaten Merauke sebesar 29.250 ha atau sekitar $60 \%$ dari luas daratan di Merauke digunakan untuk lahan pertanian. Hal ini menjadikan potensi biopestisida menjadi sangat penting terutama juga untuk pengembangan lahan pertanian organik. Saat ini masyarakat telah banyak memahami pentingnya keamanan pangan sehingga dapat dijadikan peluang yang baik untuk mengembangkan produk pertanian organik yang sehat dengan menggunakan biochar dan biopestisida organik.

Asap cair atau yang dikenal dengan cuka kayu mempunyai senyawa kimia yang sangat tepat dipakai untuk bioinsektisida alami, karena mengandung antimikroba, repllent, antifeedant, desinfekan, antioksidan, dan sebagai zat pengawet. Hasil penelitian Nugrahaini et al. (2017) yang meneliti kandungan kimiawi cuka kayu yang berasal dari sekam padi menunjukkan

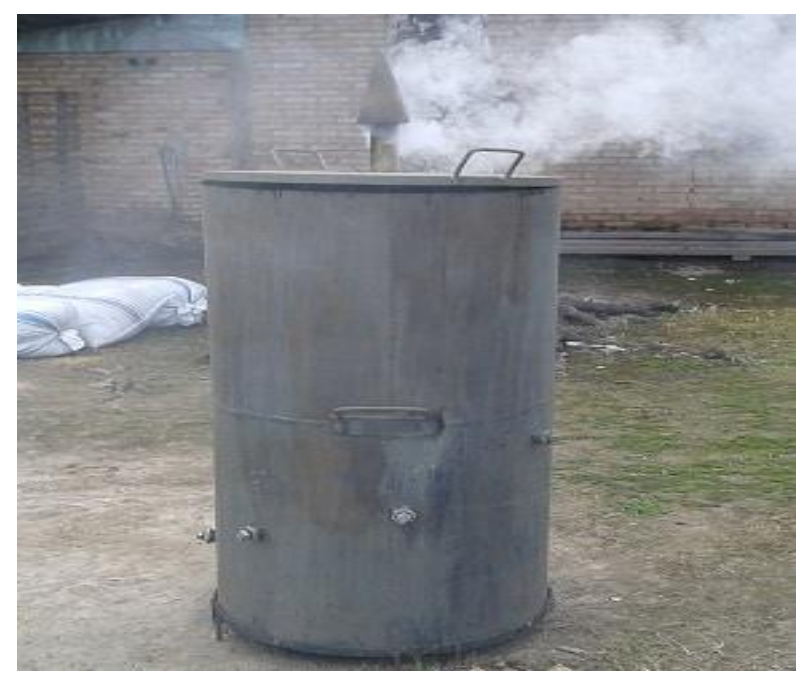

Gambar 1 Kiln drum drum saat tengah digunakan untuk memproduksi biochar. 
rendemen sebanyak 16,15\%, kadar asam kaboksilat sebesar 1,562-4,415\% dan kadar fenol 0,18-0,7\%. Penelitian Jaya et al. (2015) juga mengungkapkan hal serupa mengenai asap cair dari sekam padi terutama diamati dari proses pembuatannya. Suhu dan waktu pembakaran sangat berpengaruh terhadap kesempurnaan proses pembakaran. Pada suhu $250^{\circ} \mathrm{C}$ dan lama pembakaran selama 3 jam menghasilkan rendeman lebih tinggi sebesar 2,54\% dibandingkan pembakaran pada suhu $150^{\circ} \mathrm{C}$ dan lama pembakaran 2 jam. Sesuai dengan penelitian Putri et al. (2015) menunjukkan bahwa lama pirolisis optimum pembakaran adalah 2 jam pada interval suhu $380-430^{\circ} \mathrm{C}$. Rata-rata volume asap yang dihasilkan sebanyak 25,83 $\mathrm{mL}$ dengan $83,3 \%$ massa sekam padi setelah pirolisis.

Menurut Hagner (2013), asam asetat dan furfural yang terkandung pada asap cair merupakan senyawa yang mempunyai kemampuan untuk menolak hama siput. Penolakan terhadap hama, disebabkan keberadaan senyawa-senyawa tersebut secara bersamaan. Metanol berfungsi untuk mempercepat pertumbuhan tanaman, sedangkan phenol dan turunannya berfungsi untuk mencegah serangan hama dan penyakit tanaman. Penelitian Isa et al. (2019) menyebutkan bahwa senyawa yang terkandung pada asap cair tempurung kelapa pada konsentrasi 7\% terbukti dapat mematikan ulat grayak sebesar 88,89\%. Adapun senyawa terbanyak yang terkandung dalam asap cair tempurung kelapa adalah asam asetat sebesar $48,75 \%$, asam propanoat sebesar 4,01\%, dan fenol sebesar 3,19\%. Hasil penelitian lain menyebutkan bahwa asap cair berguna untuk memperbaiki mutu tanah dan membantu pertumbuhan tanaman agar lebih baik dan kuat serta lebih resisten terhadap hama dan penyakit (Sinar Tani 2010). Hal serupa dikemukakan oleh Yatagai (2002) bahwa asap cair mengandung komponen kimia seperti asam asetat yang berfungsi mempercepat pertumbuhan tanaman dan pencegah penyakit tanaman. Aplikasi asap cair pada tanaman dilakukan dengan cara menyemprotkannya pada seluruh daun, ranting dan cabang. Konsentrasi asap cair yang digunakan sebesar 1-2\% (dengan pelarut air) untuk pemeliharaan tanaman sehat dan apabila tanaman terserang hama, konsentrasi dapat ditingkatkan menjadi 3-5\% tergantung dari tingkat serangan. Dalam aplikasinya untuk mendapatkan hasil yang lebih baik (peningkatan diameter dan tinggi untuk tanaman kehutanan dan peningkatan produksi untuk tanaman pertanian), penggunaan asap cair dikombinasikan dengan arang kompos.
Pemberian arang dan cuka kayu dapat meningkatkan pertambahan tinggi dan diameter anakan tanaman bervariasi tergantung jenis tanaman Komarayati et al. (2014).

Dari sisi manajemen usaha, jika asap cair ini dipasarkan kepada petani di Merauke maka keberlanjutan usaha kelompok akan terjamin, karena komoditi yang dapat dijual tidak hanya mengandalkan biochar namun juga dari asap cair. Pangsa pasar asap cair di kalangan petani di Merauke sangat besar, namun belum ada petani/kelompok usaha yang memproduksi asap cair sebagai biopestisida. Kelompok sentra usaha biochar diharapkan dapat memproduksi asap cair dan membuka pasar biopestisida di Merauke. Kelompok ini telah mandiri secara teknis karena telah mendapatkan beberapa kali pelatihan dan aplikasi di lahan. Secara manajerial, kelompok ini juga mampu memberdayakan anggotanya untuk keberlanjutan usaha dengan membuat biochar secara mandiri. Walaupun terkendala dalam hal manajemen keuangan karena belum mandiri finansial. Oleh karena itu, melalui tambahan inovasi asap cair tentu memberikan peluang bagi kelompok ini untuk mandiri secara finansial. Keterbatasan lain yang dihadapi oleh kelompok adalah manajemen pemasaran. Saat ini pemasaran biochar terkendala karena kurangnya permintaan dan jangkauan pemasaran hanya di Distrik Kurik. Kelompok memiliki keterbatasan dalam hal pemasaran hingga keluar Distrik Kurik. Hal ini disebabkan karena kurangnya jaringan pemasaran, kurangnya sumber daya yang mampu membangun jejaring dan persuasi kepada petani sebagai konsumen tentang pentingnya biochar.

Tujuan peningkatan kapasitas pada masyarakat di Kampung Jaya Makmur ini adalah meningkatkan kapasitas kelompok tani melalui sosialisasi dan pelatihan pembuatan asap cair dari limbah pertanian sekam padi sebagai biopestisida organik pengganti pestisida kimia bagi kelompok tani di Kampung Jaya Makmur, Kabupaten Merauke.

\section{METODE PELAKSANAAN KEGIATAN}

\section{Waktu Pelaksanaan}

Kegiatan pelatihan pembuatan asap cair di lakukan pada bulan Mei-November 2019 diawali dengan tahap persiapan 2 bulan sebelumnya untuk merancang pembuatan modifikasi drum kiln, uji coba alat, instalasi di lapangan, mempersiapkan petani pionir, dan persiapan peserta kegiatan pelatihan. Proses pendampingan ke- 
lompok sentra produksi biochar dilakukan setelah pelatihan dilakukan hingga bulan November 2019.

\section{Lokasi dan Partisipan Kegiatan}

Kegiatan pengabdian pada masyarakat dilaksanakan di Kampung Jaya Makmur, Distrik Kurik, Kabupaten Merauke. Partisipan kegiatan ini adalah dua kelompok, yaitu kelompok tani Arwana sebanyak 22 orang, dan kelompok sentra produksi biochar sebanyak 3 orang, mahasiswa Agribisnis dan Ketehnikan Pertanian sebanyak 3 orang, dosen dari 4 jurusan (Agribisnis, Keteknikan Pertanian, Tehnik Mesin, dan Agroteknologi) sebanyak 9 orang, aparat kampung Jaya Makmur, 1 orang diwakili oleh kepala kampung dan 2 orang petani pionir dengan total peserta sebanyak 40 orang. Narasumber pelatihan berasal dari Pusat Penelitian dan Pengembangan Hasil Hutan (Puslitbang Hasil Hutan) di Bogor yang terlebih dahulu memperkenalkan asap cair biochar menjadi biopestisida dan telah memperoleh paten merek biopestisida.

\section{Bahan dan Alat}

Bahan yang digunakan dalam kegiatan ini adalah sekam padi. Alat yang digunakan adalah kiln drum yang telah dimodifikasi menjadi alat pembuat asap cair yang dilengkapi pendingin yang terbuat dari baja tahan karat dengan rancangan dan spesifikasi seperti pada Gambar 2 . Drum satu sebagai drum pembakar sekam telah pendingin yang menghubungkan drum pembakar sekam dan pendingin. Bahan drum pendingin terbuat dari drum bekas oli dengan volume $100 \mathrm{~L}$. Tutup drum pembakar terbuat dari bahan plat besi (carbon steel/CS) $3 \mathrm{~mm}$ yang disambung dengan pipa dengan diameter 3 inchi yang juga terbuat dari bahan CS. Kondensor terbuat dari bahan pipa steinless steel diameter 4 inchi yang didalamnya diisi dengan pipa stainless stell sebanyak 8 batang dengan diameter 0,5 inchi.

Proses pembuatan asap cair dilakukan dengan memasukkan $30 \mathrm{~kg}$ sekam basah atau setinggi drum pembakar. Sekam dimasukkan sedikit demi sedikit sambil dibakar melalui pipa atau dengan menggunakan pemantik berupa ranting kayu, daun kering atau kertas bekas. Setelah itu drum pembakar ditutup. Drum pendingin diisi dengan air setinggi drum dan dengan menggunakan aerator, air dialirkan naik untuk mendinginkan kondensor. Asap cair akan keluar melalui lubang keluarnya asap di bawah drum pendingin segera setelah asap pembakaran terbentuk dari pembakaran sekam.

\section{Metode Pelaksanaan Kegiatan}

Peningkatan kapasitas pada masyarakat ini merupakan pengembangan program scale up biochar yang pernah didanai oleh Simlitabmas Tahun 2016. Oleh karena itu, persiapan sosial untuk kegiatan ini hanya dilakukan satu kali, yaitu berkoordinasi dengan ketua gapoktan Jaya Makmur dan kelompok sentra produksi biochar.

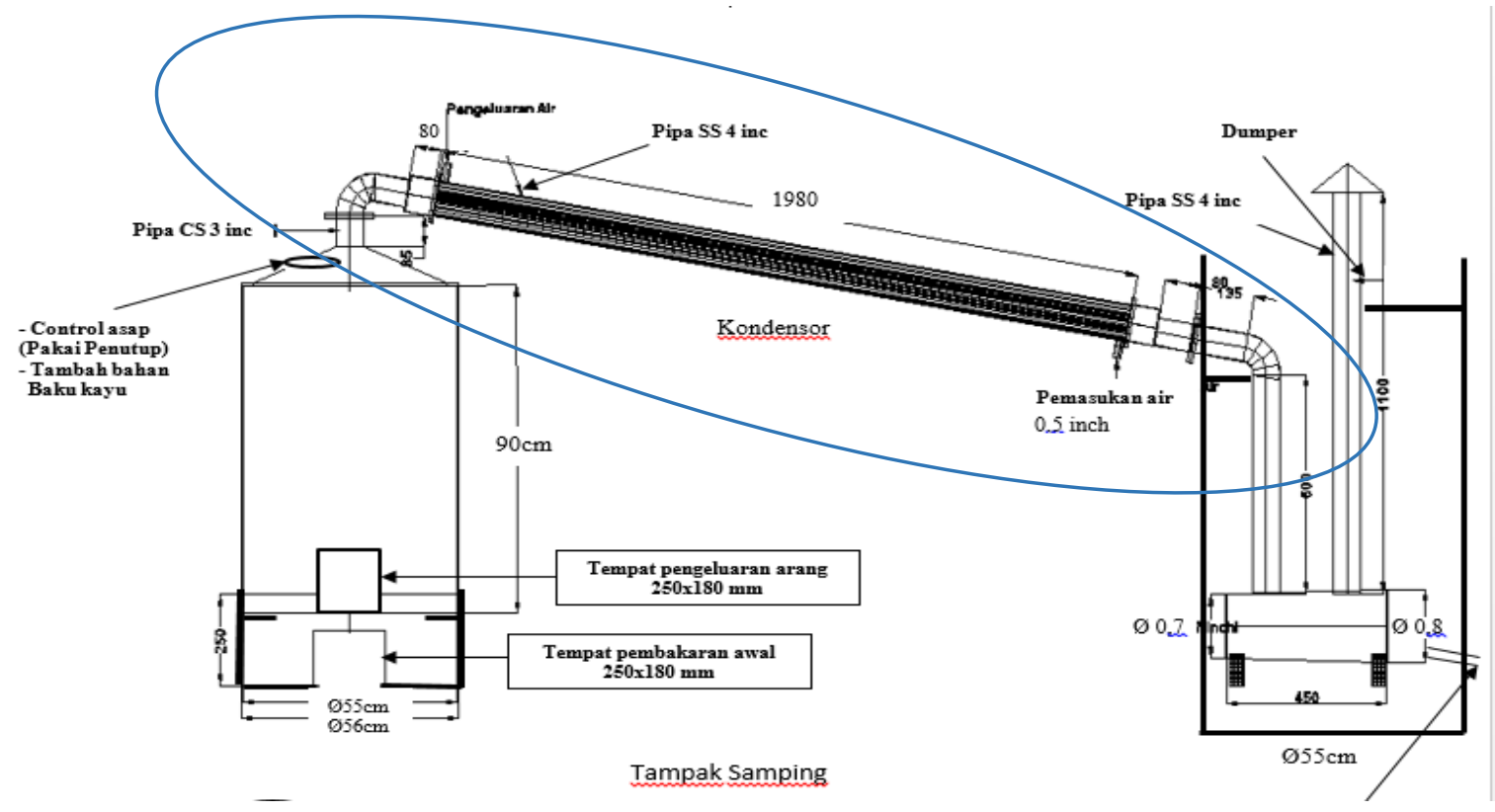

Gambar 2 Rancangan drum retort kiln (lingkaran menunjukkan alat yang akan dibuat).

dibuat sebelumnya, modifikasi yang dilakukan dengan menambah drum pendingin dan pipa
Persiapan paling penting adalah kesiapan alat yang akan didesiminasikan kepada masyarakat. 
Alat kiln drum yang sebelumnya sudah ada di kelompok, ditarik kembali untuk dimodifikasi oleh tim. Teknologi yang diadopsi merupakan teknologi yang telah dikembangkan oleh Puslitbang Hasil Hutan. Pusat penelitian dan pengembangan hasil hutan telah mengupayakan limbah kehutanan untuk dijadikan biochar dan kemudian asap cair. Program peningkatan kapasitas yang dilakukan di Kampung Jaya Makmur menggunakan limbah pertanian yang banyak terdapat di daerah target. Desain alat dan instalasi berasal dari Puslitbang Hasil Hutan, sedangkan tehnis di lapangan dilakukan oleh tim dari Jurusan Tehnik Mesin dan Ketehnikan Pertanian Universitas Musamus

Metode pelaksanaan pelatihan pembuatan asap cair menggunakan metode PLA (Participatory Learning and Action), semua peserta aktif terlibat dalam diskusi dan praktik pembuatan asap cair. Sebelum kegiatan pelatihan dilakukan, terdapat pre-test untuk mengukur tingkat pengetahuan peserta dan pada akhir pelatihan juga dilakukan post-test sebagai evaluasi kegiatan dan penyerapan materi oleh peserta pelatihan. Pre dan post-test dilakukan dengan menggunakan kuesioner yang berisi pertanyaan-pertanyaan terstruktur. Proses pengisian kusioner dipandu oleh fasilitator untuk mengatasi bias pertanyaan. Adapun tahapan pelaksanaan kegiatan pelatihan adalah sebagai berikut: 1) Membuat modifikasi drum kiln berdasarkan desain alat pembuat asap cair yang telah dibuat oleh Puslitbang Hasil Hutan; 2) Melakukan uji coba dan instalasi modifikasi drum kiln di lapangan; 3) Mempersiapkan peralatan pelatihan, fasilitator, dan tempat kegiatan; 4) Melaksanakan pelatihan pembuatan asap cair dan rencana tindak lanjut kegiatan; dan 5) Melakukan pendampingan kelompok.

\section{HASIL DAN PEMBAHASAN}

Pembuatan modifikasi alat dilakukan di laboratorium teknik mesin dan bengkel mesin, proses ini memakan waktu kurang lebih dua bulan, dengan bimbingan secara online dari Puslitbang Hasil Hutan dan dibantu oleh beberapa mahasiswa yang terdiri dari 3 jurusan, yaitu Jurusan Teknik Mesin, Keteknikan Pertanian, dan Agribisnis. Hasil modifikasi drum kiln pembuat biochar seperti yang terdapat pada Gambar 3. Drum kiln ini bisa digunakan untuk membuat asap cair sekaligus menghasilkan biochar. Pada tanggal 18 Mei 2019, alat dinyatakan selesai dibuat dan dilakukan uji coba.
Pada uji coba ini proses pembuatan asap cair berhasil dilakukan, namun terdapat beberapa perbaikan antara lain ketinggian drum baik drum pembakar maupun drum pendingin untuk memudahkan hasil biochar dikeluarkan dari drum pembakaran, dan pembuatan tempat tutup drum untuk memudahkan menambahkan sekam padi jika telah habis terbakar. Setelah perbaikan dilakukan, maka alat siap diinstalasi di desa target dan desiminasi siap dilakukan.

Kegiatan desiminasi diperuntukkan bagi kelompok tani yang sebelumnya pernah memeroleh pelatihan pembuatan biochar, namun ada pula kelompok tani yang belum pernah ikut pelatihan biochar, sehingga sosialisasi pembuatan biochar juga diberikan dalam pelatihan ini. Sebelum kegiatan pelatihan ini dimulai terlebih dahulu dilakukan pre-test bagi peserta pelatihan untuk mengetahui tingkat pemahaman peserta tentang biochar, asap cair, dan biopestisida. Setelah itu materi disampaikan, tentang apa itu biochar, asap cair, cara pembuatannya, bahan baku yang digunakan, dan manfaat bagi lahan pertanian. Suasana pelatihan di dalam ruang aula balai Kampung Jaya Makmur dapat dilihat pada Gambar 4. Setelah itu diadakan

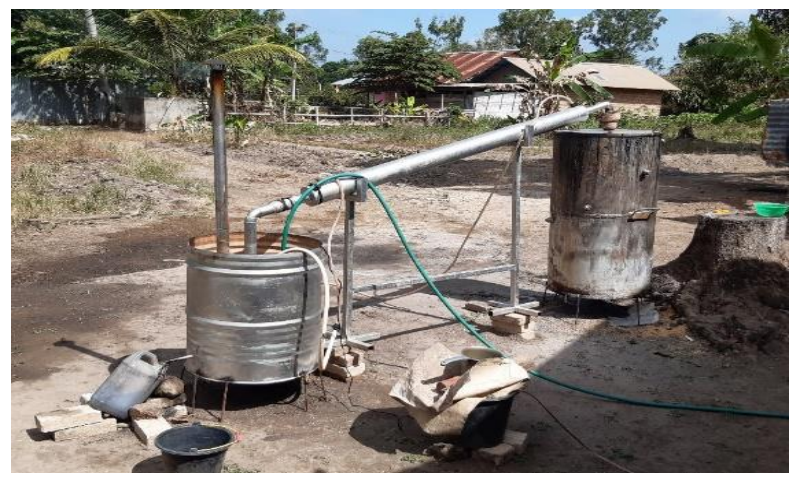

Gambar 3 Hasil modifikasi drum retort kiln biochar menjadi alat pembuat asap cair sekam.

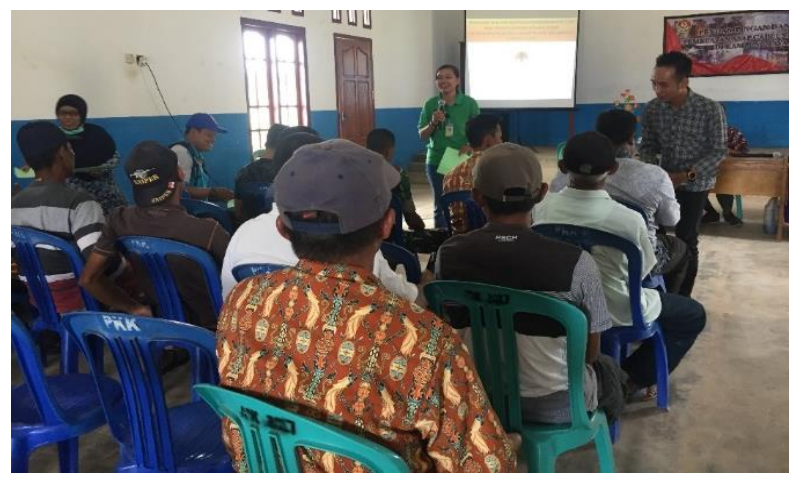

Gambar 4 Pelatihan Gapoktan dalam pembuatan asap cair sekam untuk biopestisida.

sesi tanya jawab dan demonstrasi pembuatan asap cair dari bahan baku sekam dengan 
menggunakan drum kiln yang telah dimodifikasi. Dalam demonstrasi ini tanya jawab juga berlangsung antara peserta dan fasilitator, hal ini dapat dilihat pada Gambar 5. Peserta nampak antusias terlihat dari banyaknya pertanyaan mengenai proses kerja alat dan asap cair yang dihasilkan. Bahkan ada peserta yang tidak percaya bahwa sekam padi yang selama ini dibuang ternyata bisa membawa manfaat sebagai pestisida bagi tanaman. Mereka tertarik untuk mencoba mempraktikannya di lahan pertanian mereka sendiri. Pertanyaan yang diajukan sangat teknis dan seputar mengenai pemakaian biopestisida di lahan sawah. Bagaimana aplikasinya, kapan, dan berapa takaran yang digunakan jika ingin diaplikasikan. Biopestisida ini sebaiknya digunakan sebagai preventif untuk mencegah datangnya hama, namun jika hama sudah menyerang, pemakaian biopestisida asap cair dapat digandakan. Pada lahan sawah pemakaiannya sebanyak 1-2\% (dicampur air). Selain dapat mengurangi hama dan penyakit tanaman, aplikasi asap cair pada padi dapat meningkatkan jumlah rumpun padi sehingga produksi meningkat. Hasil penelitian puslithutan pada tanaman padi, biaya pestisida berkurang dari Rp 750.000/ha menjadi Rp 500.000/ha (dengan asumsi harga asap cair Rp 20.000/L) dan beras yang dihasilkan sebanyak 3,89 ton/ha jika dibandingkan dengan menggunakan pestisida kimia hanya menghasilkan 2,84 ton/ha. Selain ini penampakan fisik menunjukkan bahwa pemakaian asap cair pada tanaman padi dapat mengurangi serangan tikus, batang padi tidak roboh pada serangan wereng, dan ulat bulu berkurang $90 \%$. Selain pada tanaman padi, asap cair juga dapat diaplikasikan pada tanaman buah, tanaman kehutanan, tanaman perkebunan, antara lain mangga, cabai, sengon, dan kelapa sawit. Aplikasi asap cair $0,5-1 \%$ pada tanaman mangga dapat mempercepat berbuah. Aplikasi

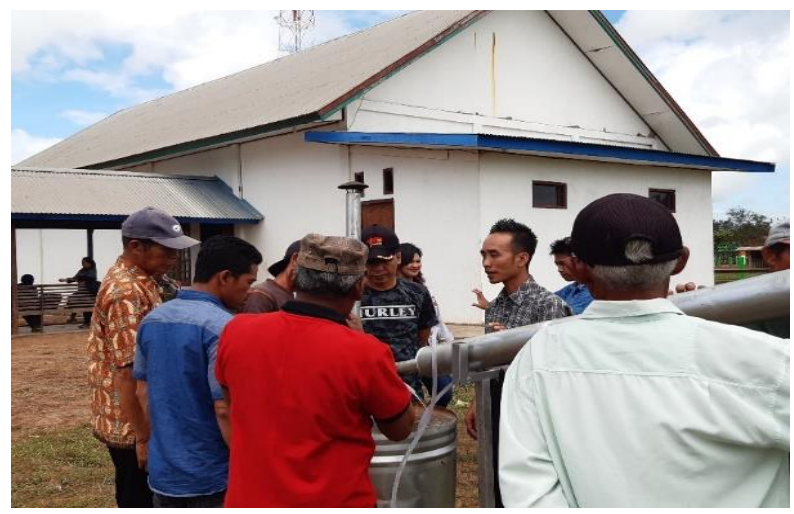

Gambar 5 Tim fasilitator memberikan penjelasan kepada anggota gapoktan.
4\% pada tanaman anakan pinus dapat merangsang pertumbuhan yang semula layu menjadi segar kembali dan dapat tumbuh dengan baik.

Setelah pelatihan dilakukan, proses pendampingan terus dilakukan untuk memastikan keberlanjutan program. Asap cair yang telah dihasilkan kemudian dianalisis kandungan mutunya di laboratorium penelitian hasil hutan di Bogor. Hasil analisis menunjukkan bahwa kandungan asam asetat sebesar $42 \%$ dan fenol sebesar $20,58 \%$. Hasil analisis kadar asam asetat dan fenol tersebut sedikit lebih rendah dari asap cair yang berasal dari tempurung kelapa. Sebagai perbandingan asam asetat sebesar $49,54 \%$ dan fenol sebesar 20,91\% dari asap cair tempurung kelapa. Fenol dapat mencegah serangan hama dan penyakit pada tanaman, begitupula dengan asam setat dapat menpercepat pertumbuhan pada tanaman dan mencegah penyakit. Aplikasi asap cair di lahan pertanian belum dilakukan dan direncanakan akan dilakukan uji coba di lahan petani pioner pada musim tanam berikutnya (menunggu konfirmasi ketersediaan asap cair untuk uji coba). Saat ini merek dagang telah didiskusikan dan untuk sementara menggunakan merek asap cair Sepagati (sekam padi grade tiga). Untuk kemasan dan label masih dalam proses pembuatan. Pendampingan kelompok juga dilakukan terhadap produksi dan manajemen kelompok. Saat ini, kelompok sentra biochar telah berhasil dan memanfaatkan alat pembuat asap cair ini bahkan telah menghasilkan kurang lebih $30 \mathrm{~L}$ asap cair yang siap untuk diaplikasikan dan diuji coba ke lahan pertanian. Dari hasil pendampingan diperoleh informasi bahwa ratarata pembakaran sekam per hari $50 \mathrm{~kg}$ yang akan menghasilkan asap cair sebanyak 5,5 L selama 15 jam.

Publikasi produk kepada petani lain dan melalui media massa terus dilakukan dalam proses pendampingan kelompok. Produk asap cair yang dihasilkan telah dibagikan kepada petani yang ingin mempraktikkan pertanian organik dengan menggunakan biopestisida. Petani tomat, padi, dan sayuran yang terdapat di kota Merauke dan kelompok mama-mama di Kelapa Lima telah dibagikan produk ini sebagai bentuk sosialisasi kepada masyarakat.

Dalam proses evaluasi dan pendampingan, ada beberapa hal yang perlu dilakukan antara lain biochar/arang sekam yang seharusnya menjadi produk sampingan ternyata tidak dapat dihasilkan dalam proses ini karena sekam dibiarkan terbakar hingga habis. Menurut Pak 
Rajimun ketua kelompok, tidak efesien untuk mengeluarkan arang sekam karena biasanya proses pembakaran ditinggal selama seharian sementara pergi ke lahan sawah untuk bekerja. Hal ini perlu dipertimbangkan oleh tim dalam hal efesiensi dan efektivitas alat. Kendala ini menjadi agenda bagi anggota tim dari Teknik Mesin dan Keteknikan Pertanian. Pada pendampingan terakhir telah dilakukan analisis usaha sederhana untuk menentukan harga asap cair yang telah diproduksi. Harga sementara ditetapkan sebesar Rp 50.000 untuk kemasan $5 \mathrm{~L}$ asap cair. Harga ini merupakan harga promosi karena untuk memenuhi biaya dan memeroleh keuntungan, setidaknya harga jual per $5 \mathrm{~L}$ asap cair sebesar Rp 100.000. Penetapan harga ini ditetapkan bersama dengan pertimbangan karena komoditas ini merupakan komoditas baru dan belum diujicobakan di lahan pertanian di Merauke. Setelah proses perkembangan selanjutnya akan dikaji kembali harga jual dan kemasan serta strategi promosinya. Sebagai perbandingan harga asap cair yang berasal dari tempurung kelapa dijual dengan harga $\mathrm{Rp}$ 20.000-45.000/L Pertiwi \& Khoiriyah (2016). Penelitian Novita (2011) mengenai analisis ekonomi pembuatan asap cair dari sekam padi menunjukkan nilai BEP yang tinggi yang berarti bahwa biaya produksi masih lebih tinggi sebesar Rp 35.801,67/kg dibandingkan harga jual asap cair per kg yang berlaku di Padang, yaitu pada kisaran Rp 21.000-25.000/kg. Bahan baku asap cair yang dapat memberikan keuntungan berasal dari tempurung kelapa dan tongkol jagung. Penelitian Novita (2011) menunjukkan bahwa asap cair dari bahan baku sekam padi tidak efesien karena biaya produksi lebih tinggi dibandingkan harga jual di pasar. Hal ini dikarenakan bahan baku sekam padi di Padang sudah memiliki nilai ekonomis, sedangkan harga sekam padi di Merauke masih sangat murah.

\section{Dampak Kegiatan}

Kegiatan ini telah meningkatkan pengetahuan petani. Peningkatan ini dapat dibuktikan dari hasil pre-test dan post-test. Pada saat pre-test, tingkat pengetahuan petani tentang biochar menunjukkan $67 \%$ peserta pelatihan tidak tahu tentang biochar, dan 33\% tahu mengenai biochar. Dari peserta yang mengetahui tentang biochar, $50 \%$ menjawab dengan benar dan 50\% menjawab kurang tepat. Peserta lebih mengetahui biochar sebagai bahan untuk menyemprot tanaman (sebagai pestisida/obat untuk tanaman).
Namun yang menjawab "tahu" biochar mengatakan benar bahwa bahan baku biochar bisa terbuat dari sekam padi.

Pengetahuan peserta pada saat pre-test mengenai asap cair menunjukkan bahwa $75 \%$ tidak tahu tentang asap cair dan $25 \%$ peserta yang tahu tentang asap cair menunjukkan pengetahuan yang kurang tepat. Peserta yang mengaku tahu tentang asap cair mengatakan bahwa asap cair digunakan untuk pemupukan dan menyuburkan tanah. Hasil pre-test juga menunjukkan bahwa 97\% peserta tidak tahu tentang biopestisida. Rata-rata pengetahuan peserta sebelum dan sesudah pelatihan terhadap konsep biochar, asap cair, dan biopestisida terlampir dalam Gambar 6.

Dalam pre-test ini juga ditanyakan kepada peserta berapa rata-rata biaya yang dikeluarkan oleh petani untuk membeli pestisida dalam satu kali musim tanam. Hasil jawaban peserta ratarata petani mengeluarkan uang sebesar $\mathrm{Rp}$ 1.155.556 untuk setiap musim tanam. Informasi ini digali untuk mengetahui berapa besarnya pengeluaran petani untuk membeli pestisida yang nantinya dapat digantikan oleh asap cair sebagai biopestisida.

Setelah pelatihan dilakukan, kuesioner kembali disebarkan untuk mengetahui tingkat pemahaman peserta terhadap materi yang disampaikan. Hasil post-test menunjukkan bahwa 57\% peserta menjadi tahu tentang biochar, asap cair, dan biopestisida dan dapat menyebutkan dengan tepat apa itu biochar, asap cair, dan biopestisida. Sebanyak $43 \%$ peserta tidak menjawab pertanyaan dalam post-test. Hal ini diduga karena waktu pengisian post-test sangat sempit mengingat waktu kegiatan telah selesai. Beberapa peserta bukan tidak tahu melainkan enggan menjawab karena waktu yang terlalu sempit.

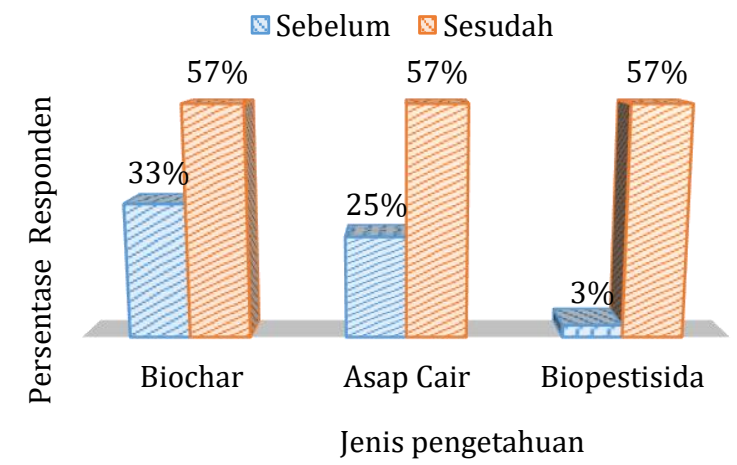

Gambar 6 Tingkat pengetahuan peserta sebelum dan sesudah pelatihan pembuatan asap cair dari sekam padi. 
Tingkat penguasaan pengoperasian alat dan penguasan dalam penggunaan alat pembuat asap cair ini dilihat pada saat praktek dalam kelompok sentra produksi biochar. Kelompok ini secara terpisah berupaya untuk mengoperasikan alat dan berhasil memperoleh asap cair, dari enam kali pembakaran sekam padi telah dihasilkan kurang lebih $30 \mathrm{~L}$ asap cair. Hal ini menunjukkan bahwa tingkat penguasaan pengoperasian dan penggunaan alat $100 \%$ dapat dipahami oleh peserta dari kelompok sentra produksi biochar.

Pertanyaan terakhir yang dijawab oleh peserta pelatihan tentang apakah mereka bersedia untuk menggunakan biopestisida dari asap cair sekam untuk lahan pertanian mereka. Sebanyak 93\% peserta menjawab mau menggunakan biopestisida dengan beberapa alasan. Alasan terbanyak sebesar $64 \%$ adalah mereka mau menggunakan biopestisida asalkan barang sudah tersedia. Alasan lain dari peserta mereka mau menggunakan biopestisida untuk mengurangi biaya pembelian pestisida, mereka mau mengetahui hasilnya ketika sudah diaplikasikan, mereka mau menggunakan asalkan sudah diuji coba di lahan pertanian di Kampung Jaya Makmur dan terbukti hasilnya dapat mengurangi hama dan biaya pembelian pestisida.

Hasil pre-test dan post-test ini menunjukkan bahwa telah terjadi perubahan pengetahuan di tingkat petani dan telah dicapai kesepakatan bahwa petani bersedia untuk menggunakan biopestisida. Untuk mengatasi ketersediaan biopestisida ini maka kelompok sentra produksi biochar akan berupaya untuk melanjutkan proses pembuatan asap cair dan menyediakan barang yang dibutuhkan oleh petani. Hal ini terungkap dalam statement ketua kelompok sentra produksi biochar, Bapak Rajimun. Pendampingan terhadap kelompok ini menjadi salah satu bentuk dukungan yang diberikan oleh akademisi agar tujuan utama pertanian berkelanjutan dan keamanan pangan dapat samasama diwujudkan oleh petani-petani di Kampung Jaya Makmur.

\section{Upaya Keberlanjutan Kegiatan}

Hasil evaluasi bersama tim, kepala kampung dan kelompok tani menyatakan bahwa mereka berharap kegiatan ini harus berlanjut. Untuk itu upaya yang akan dilakukan untuk menjamin keberlanjutan program antara lain: pertama, proses pendampingan terus dilakukan kepada kelompok sentra produksi biochar agar dapat memanfaatkan mesin pembuat asap cair yang telah diserahkan kepada kelompok. Diharapkan produksi dapat kontinu dan menghasilkan produk biopestisida yang bisa digunakan oleh petani sesuai dengan harapan dari petani yang tertulis dalam post test saat pelatihan. Termasuk dalam pendampingan ini adalah maintenance alat pembuat asap cair agar dapat diketahui kekurangan dari alat tersebut dan dapat diperbaiki pada pembuatan versi kedua mesin pembuat asap cair. Pendampingan juga dilanjutkan dengan melakukan uji coba menggunakan bahan baku yang lain seperti limbah kayu, tempurung kelapa, atau serasah. Pendampingan ini rencananya dilakukan rutin sebulan sekali.

Kedua, mendesain dan menentukan merek yang menarik untuk kemasan asap cair yang dihasilkan. Jerigen yang menjadi kemasan asap cair dengan volume $5 \mathrm{~L}$, telah diserahkan kepada kelompok untuk mendukung produksi perdana. Ketiga, rencana pembuatan proposal untuk demplot aplikasi biopestisida dilahan pertanian di kampung Jaya Makmur. Telah disepakati lahan yang akan digunakan dan persiapan biopestisida yang akan digunakan untuk proses uji coba dilahan. Proposal penelitian akan digunakan untuk memeroleh dana kegiatan untuk perjalanan dan monitoring aplikasi biopestisida di lapangan. Rencana pembuatan proposal juga akan dibuat untuk modifikasi alat pembuat asap cair versi kedua. Alat modifikasi drum kiln yang telah ada ini perlu mengakomodir beberapa kebutuhan misalnya biochar harus pula dihasilkan dalam proses ini, kebocoran asap yang masih terjadi di beberapa tempat, desain pipa pendingin yang masih perlu diperbaiki. Diharapkan dengan adanya mesin pembuat asap cair versi kedua ini, asap cair yang dihasilkan dapat lebih banyak dan mengefesienkan biaya produksi. Perbaikan alat juga dapat mengacu pada hasil penelitian Aliyanto (2013) yang merancang alat pirolisis asap cair khusus untuk sekam padi dengan kapasitas $50 \mathrm{~kg}$ per produksi. Spesifikasi yang dihasilkan badan oven: diameter bagian dalam $1 \mathrm{~m}$, tebal $1 \mathrm{~mm}$, dan tinggi $900 \mathrm{~mm}$. Bahan yang digunakan konstruksi baja SC 37. Tabung api yang digunakan ukuran 1 ichi, tinggi $1.000 \mathrm{~mm}$ dengan bahan baja yang sama. Untuk kondensor menggunakan susunan pipa balok membentuk spiral bahan konstruksi tembaga ukuran 12 inchi, jarak pipa spiral 0,02 m, panjang pipa 340, $22 \mathrm{~m}$, dan jumlah belitan 107 putaran. Kapasitas mesin pembuat asap cair ini dapat menggunakan bahan baku sebanyak $54 \mathrm{~kg}$ sekam padi dengan waktu pembakaran 2,54 jam.

Empat, pendampingan kelompok dalam pengelolaan manajemen kelompok juga terus 
dilakukan terutama untuk pembukuan dan perhitungan untung rugi usaha pembuatan biopestisida. Alat pembuat asap cair ini diberikan kepada kelompok sentra produksi biochar yang selama ini menggunakan rumah ketua kelompok sebagai lokasi produksi. Mekanisme untuk pembuatan asap cair dilakukan secara bergantian antara anggota kelompok sentra produksi biochar. Termasuk dalam pengumpulan bahan baku berupa sekam padi. Masing-masing anggota kelompok secara rutin mengambil sekam padi di penggilingan padi pada saat pulang dari sawah dengan membawa traktor dan disimpan di rumah ketua kelompok. Untuk sementara produksi asap cair dan biochar masih on demand atau berdasarkan permintaan, karena sosialisasi mengenai biopestisida ini baru akan digalakkan melalui kelompok-kelompok tani.

\section{SIMPULAN}

Peningkatan kapasitas kepada masyarakat melalui pelatihan pembuatan asap cair dari limbah sekam padi menjadi biopestisida telah dilakukan kepada 2 kelompok tani di Kampung Jaya Makmur. Alat pembuat asap cair telah dibuat dari modifikasi kiln drum biochar dengan menambahkan drum pendingin dan pipa kondensor yang dapat menangkap asap dan mengubahnya menjadi asap cair. Cara pembuatan asap cair, prinsip kerja alat dan pengoperasian alat telah diinformasikan dan dilatih kepada kelompok tani dan kelompok sentra produksi biochar. Cara aplikasi biopestisida pada tanaman padi dan manfaatnya juga telah diinformasikan kepada kelompok tani. Peserta pelatihan juga telah melihat langsung cara pembuatan asap cair dan mengenali biopestisida dari asap cair sekam. Stimulasi bantuan berupa satu unit instalasi alat pembuat biochar dan asap cair, kemasan dan label telah diberikan kepada kelompok sentra produksi biochar. Pendampingan terus dilakukan kepada kelompok sentra produksi biochar agar dapat memproduksi asap cair secara rutin. Pengetahuan peserta pelatihan mengenai asap cair, biochar dan biopestisida meningkat sebesar $57 \%$ sebelum pelatihan dilakukan.

Saran dari petani untuk program ini adalah keberlanjutan. Petani menunggu kepastian ketersediaan biopestisida dari kelompok sentra produksi biochar yang akan memproduksi asap cair. Petani juga menantikan hasil ujicoba aplikasi asap cair di lahan pertanian di Kampung Jaya Makmur.

\section{UCAPAN TERIMA KASIH}

Terima kasih kepada Kementerian Riset Teknologi dan Perguruan Tinggi yang telah memberikan pendanaan untuk kegiatan PKM 2019. Terima kasih juga kepada Gapoktan di Kampung Jaya Makmur, petani pionir (Rajimun dan Riski) yang telah berdedikasi untuk pengembangan biochar dan asap cair.

\section{DAFTAR PUSTAKA}

Aliyanto. 2013. Perancangan Alat Pirolisis Asap Cair dari Sekam Padi Kapasitas 50 kg per proses. [Thesisi]. Malang (ID): Universitas Muhamadiyah Malang.

[BPS] Badan Pusat Statistik Kabupaten Merauke. 2017. Merauke Dalam Angka 2016. Merauke (ID): Badan Pusat Statistik Kabupaten Merauke.

Hagner M. (2013). Potential of the slow pyrolisis products birch tar oil, wood vinegar and biochar in sustainable plant protectionpesticidal effects, soil improvement risks. Finland (FI): Departement of Enviromental of Helsinki, Lahti.

Isa I, Musa WJ, Rahman SW. 2019. Pemanfaatan asap cair tempurung kelapa sebagai pestisida organik terhadap mortalitas ulat grayak (Spodoptera litura F.). Jambura Journal of Chemistry. 01(1): 15-20. https://doi.org/ 10.34312/jambchem. v1i1.2102

Jaya DJ, Zulmi A, Wahyudi D, Kartika WH, Yuliana N, Kholis N. 2015. Optimasi pembuatan asap cair dari sekam padi dan aplikasinya sebagai pupuk tanaman hidroponik. Jurnal Teknologi Agro-Industri. 2(2): 28-32. https://doi.org/ 10.34128/jtai.v2i2.17

Komarayati S, Gusmailina, Gustan P. 2014. Pengaruh arang dan cuka kayu terhadap peningkatan pertumbuhan dan simpanan karbon. Jurnal Penelitian Hasil Hutan. 32(4): 313-328. https://doi.org/10.20886/jphh. 2014.32.4.313-328

Novita S. 2011. Kinerja dan analisis teknoekonomi alat penghasil asap cair dengan bahan baku limbah pertanian. Padang (ID): Universitas Andalas. 
Nugrahaini D, Laila KE, Tarwotjo U, Prianto AH. 2017. Identifikasi kandungan senyawa kimia cuka kayu dari sekam padi. Jurnal BIOMA. 19(1): 30-37. https://doi.org/10.14710/ bioma.19.1.30-37

Pertiwi SD, Khoiriyah R. 2016. Kontan. [Internet]. [Diakses pada: 10 Nov 2019]. Tersedia pada: http://kontan.co.id.

Putri ER, Mislaini, Ningsih SL. 2015. Pengembangan alat penghasil asap cair dari sekam padi untuk menghasilkan insektisida organik. Jurnal Teknologi Pertanian Andalas. 19(2): 29-36.

Sinar Tani. 2010. Cuka kayu penyubur dan penguat tanaman. Jakarta (ID): Sinar Tani.
Widiastuti MM. 2018. Economic Impact of Pesticides and Biosecurity Agriculture Development in Merauke Border Area of RI$P N G$. Bali (ID): Masterclass Biosecurity. https://doi.org/10.31227/osf.io/vcnp7

Widiastuti MM, Lantang B. 2017. Pelatihan pembuatan biochar dari limbah sekam padi menggunakan metode retort kiln. Agrokreatif Jurnal Ilmiah Pengabdian kepada Masyarakat. 3(2): 129-135. https://doi.org/10.29244/ agrokreatif.3.2.129-135

Yatagai. 2002. Utilization of charcoal and wood vinegar in Japan. Jepang (JP): The University of Tokyo. 